\title{
ICEBERG ACCUMULATIONS AS COASTAL FEATURES IN ANTARCTICA
}

At a number of places along the Antarctic coast accumulations of grounded icebergs extend from the shore out into the sea for distances often exceeding 60 miles. In some cases they represent an extension of a glacier tongue which already protrudes some distance from the coast, in others, they appear to have no glacier tongue as their coastal root.

Water sufficiently shallow for stranding the icebergs is a necessary condition for the formation of both types of feature. It is significant that the northern tip of these iceberg tongues invariably coincides with the edge of the continental shelf. Frequently, even in summer, the spaces between the separated icebergs remain choked with fast ice or bay ice so that the iceberg tongue presents a semi-permanent and impenetrable obstacle to ships of every kind. However, in some cases ocean currents appear to sweep away the sea ice in summer, leaving navigable water in narrow lanes between the icebergs.

Because of the length of iceberg tongues, ships attempting to sail along the Antarctic coast are forced to make long northward detours to avoid them. The object of this letter is to stress the importance of iceberg tongues as coastal features in Antarctica, and to make a plea for their accurate delineation on charts. So far little attention has been paid to these features except in the case of the Ninnis and Mertz Glacier Tongues. Where other glacier tongues have been mapped, the seaward extensions of separated icebergs beyond the limits of the solid tongues have generally not been marked, even though they may have been solidly welded together with semi-permanent bay ice.

In 1956, 1958, 1959 and 1960, the ANARE investigated the Dibble Glacier iceberg tongue (long. $135^{\circ} \mathrm{E}$.) and delineated its approximate western edge. In each of these summer seasons our ship was forced to detour 70 miles to the north of the main coastline before it could penetrate this tongue. In 1956 and 1960 we investigated a similar iceberg tongue which extended northwards from Cape Southard (long. 121 ${ }^{\circ}$ E.) for 70 miles. Another such tongue appears to extend from Cape Mose (long. $130^{\circ} \mathrm{E}$.) northwards for 70 miles to about lat. $65^{\circ} \mathrm{S}$. and from Cape Goodenough (long. $127^{\circ} \mathrm{E}$.) to about $65^{\circ} 20^{\prime} \mathrm{S}$. From the Totten Glacier Tongue (long. $117^{\circ} \mathrm{E}$.) there almost certainly extends a similar feature. Smaller features may exist at many other places.

Examples of iceberg accumulations in the Australian sector which can be penetrated by ships in summer, probably because currents sweep the grounded icebergs free of obstructing sea ice, are those of the Petersen Bank (long. $111^{\circ} \mathrm{E}$.) which extend 50 miles north from "Wilkes" station, those of the Four Ladies Bank (long. $78^{\circ}$ E.) near Davis station and those of the Fram Bank (long. $71^{\circ} \mathrm{E}$.).

Information concerning the permanence of iceberg tongues and glacier tongues is required. The glacier tongue of the Glacier du Français, at Dumont d'Urville, last summer was found to have practically disappeared, and the 
present extensions of the Ninnis and Mertz glacier tongues are apparently far short of what they were when Sir Douglas Mawson first mapped them.

ANTARCTIC DIVISION,

PHILLIP LAW

DEPARTMENT OF EXTERNAL AFFAIRS,

MELBOURNE, AUSTRAIIA

8 June 1960

\section{THE EDGE OF THE ANTARCTIC CONTINENTAL SHELF}

On British and Commonwealth charts of coastal waters the 100-fathom contour is shown, where it exists. This contour has come to be accepted as the edge of the continental shelf. Charts produced for navigational purposes do not delineate the shelf as such.

On Admiralty charts of Antarctica the 100-fathom line and the 1000-fathom line are shown. Charts by the United States Hydrographic Office for Antarctica show the 100-fathom line, 500-fathom line and 1000-fathom line. Charts by the USSR Hydrographic Office show the $200-\mathrm{m}$. line, 500-m. line, $1000-\mathrm{m}$. line and $2000-\mathrm{m}$. line; the areas within the limits of the first three are shaded.

The author considers that a precise criterion should be used for the delineation of the continental shelf in Antarctica. This shelf in many places extends 60 to 100 miles from the coast, it is deeper than that of other continents, its position is of great interest to navigators, oceanographers, biologists, glaciologists and others, and its limit is fairly obviously defined by the very sudden lunge of the sea bed to oceanic depths.

In a number of separate voyages since 1954, the ANARE have carried out ocean soundings from the Kista Dan, the Thala Dan and the Magga Dan. In each approach towards the Antarctic continent care has been taken to record the position where the sudden rise of the sea bed on to the continental shelf occurred, and conversely. when leaving Antarctica. The depth of the shelf varieg considerably between shoal depths and about $500 \mathrm{~m}$., but most of the shelf soundings lie in the range 300 to $500 \mathrm{~m}$. The transition in depth is shown by the following examples, taken when leaving the shelf:

480 to $1640 \mathrm{~m}$. and deeper in 5 miles of sailing;

380 to $2000 \mathrm{~m}$. and deeper in 7 miles of sailing.

I would like to suggest that maps and charts of Antarctic water delineate as accurately as possible the edge of the continental shelf, using as a criterion not some arbitrarily chosen depth (e.g. 400 fathoms) but the place, irrespective of small variations in depth, where the fairly level sea bed of the continental platform suddenly turns downward to plunge to great depths. This exact, rather than arbitrary, delineation would be of interest to many users of the charts.

PHILLIP LAW

ANTARCTIC DIVISION,

DEPARTMENT OF EXTERNAL AFFAIRS,

MELBOURNE, AUSTRALIA

8 June 1960 